\title{
Article \\ Active Methodologies in Physical Education: Perception and Opinion of Students on the Pedagogical Model Used by Their Teachers
}

\author{
Emilio Crisol Moya ${ }^{1}$ (D) and María Jesús Caurcel Cara ${ }^{2, *(D)}$ \\ 1 Department of Didactics and School Organization, University of Granada, 18071 Granada, Spain; \\ ecrisol@ugr.es \\ 2 Department of Developmental and Educational Psychology, Faculty of Education, University of Granada, \\ 18071 Granada, Spain \\ * Correspondence: caurcel@ugr.es; Tel.: +34-958-249-896
}

Citation: Crisol Moya, E.; Caurcel Cara, M.J. Active Methodologies in Physical Education: Perception and Opinion of Students on the Pedagogical Model Used by Their Teachers. Int. J. Environ. Res. Public Health 2021, 18, 1438. https:// doi.org/10.3390/ijerph18041438

Academic Editors: Gallotta Maria Chiara and Mirja Hirvensalo Received: 10 January 2021

Accepted: 1 February 2021

Published: 3 February 202

Publisher's Note: MDPI stays neutral with regard to jurisdictional claims in published maps and institutional affiliations.

Copyright: (c) 2021 by the authors. Licensee MDPI, Basel, Switzerland. This article is an open access article distributed under the terms and conditions of the Creative Commons Attribution (CC BY) license (https:// creativecommons.org/licenses/by/ $4.0 /)$.

\begin{abstract}
The teaching of physical education today still incorporates innovative methodologies in order to create quality physical education. This article sets out to describe which pedagogical model is used in the initial training of physical education teachers at the University of Granada, from the perspective of the students. The study adopted an exploratory, descriptive and comparative research design, applying a survey to a sample of 303 physical education students. The students perceive that their teachers make use of different organising modalities, methodological strategies and assessment systems that favour the use of active methodologies. The structural equations model for analysing predictive relations between the three methodological components (organising modalities, methodological approaches and evaluation systems) was fitted correctly, obtaining positive relations between the three components. The model also showed positive and negative influences in the opinion of the students in the planning of the teaching-learning methodologies and some of the methodological components. The results indicate that the perception and opinion of the physical education students take on a special role in the development of student-centred methodologies.
\end{abstract}

Keywords: active methodologies; perception; opinion; physical education; university students

\section{Introduction}

Education today has inherited a tradition characterised by a one-size-fits-all methodology [1] aimed at an education focused on content, materials, pacing and method [2].

However, there are other forms of education that seek to reinvent education, such as neuro-education. This is a new vision of teaching that provides educational strategies and technologies that are based on how the brain functions. This educational discipline brings together knowledge on neuroscience, psychology and education with the aim of optimising the teaching-learning process [3] through the creation of innovative teaching methodologies, formed from data provided by neuro-education [4].

Through this premise, students are not limited to passively receiving information; rather, they handle it, participating actively in its creation [5]. This idea has led to the promulgation of the concept of active methodology, which is a new form of transmitting and creating knowledge that is shared and developed by the students themselves, under guidance from the teacher for an optimal achievement of objectives [6], and the consolidation of content [7-9].

In the initial training of physical education teachers, as well as the specific content of the discipline, there is a need to deliberately tackle a range of methodological aspects that are transferable to the classroom and that will develop their professional activity [10]. These are related to teaching plan designs, organising groups, time management and applying assessments. All these aspects are clearly involved in the development of new pedagogical 
models [11], which are envisaged as facilitating and encouraging critical thought [12], engaging the students with problems from the real world that they will go on to play a part in. Based on an interdependent relationship between teaching, learning, content and context, active methodologies are thus framed within pedagogical models [13]. This approach is supported by the UN, as part of the framework of aims from the 2030 Agenda for Sustainable Development, which propounds an educational model that endeavours to attain the development of student competence through a learning-centred model by way of active methodologies. Conveying a model correctly is as important as learning it. In this way, there is some bridging of the gap that tends to exist between the theoretical evidence in the training guidelines of physical activity and its subsequent use in the actual classroom [14]. Different methodological concepts have emerged along these lines, which take up this type of approach and discourse in the area of physical education, producing proposals that aim to be an alternative to traditional ways of understanding and practising physical education [15]. Therefore, in agreement with the current guidelines from international and national reports, which set out the policies for giving quality physical education, the use of more open methodologies is advocated-open methodologies that involve the active participation of students in their learning, based on context and competences. This means that more traditional models-understood as those focused on teaching and performance-are left behind [5].

In the literature, quite a few publications have over time recommended using the learning-centred model in different areas of knowledge [16-28], while other studies have analysed its use in practice [29-44], with many focusing on physical education [5,45-57]. These studies make it clear that a methodological redevelopment is underway that involves the use of new forms of organisation (modalities of organisation), teaching methodologies (methodological approaches), and assessment processes (assessment systems) [58-61]. These align with the new professional profiles and a new way of understanding learning that is crucial for the transition from a teaching-based methodology to one based on encouraging active learning [62-64].

Of the many broad definitions of active learning, all of them involve more than just passive listening [56,58,63,65-69]. Active learning is a broad term and, in common use, is "generally defined as any instructional method that engages students in the learning process" [70].

This new focus of the teaching practice has brought about an increase in motivation [35-71] and an improvement in student attitude [72], due to the new opportunities and media of learning that they have at their disposal [73], bringing modern education closer to the peculiarities of digital society [74]. This has made it possible not only to make use of new ways of conveying content but also the appearance of new spaces and times for the instructive process [7], which is known as ubiquity [75].

The use of active methods in university classrooms is effective as long as the teacher takes student participation into account in the organisation and design of the teachinglearning methodologies, as well as in the assessment methods [64,76-79].

The theory behind the use of active methodologies is based on a constructivist view of learning [79-81]. Being constructive means guaranteeing that all the components of the teaching-learning process are developed unanimously, so that both the methodological approaches (teaching methods) and the assessment systems (evaluation procedures) are designed to achieve the desired learning competences and results [63,64].

The problem with this methodology, which encourages active learning, is that it is often poorly applied or not applied at all, with the result that the active methodologies are only actually present in theory. It is not enough that the use of active methodologies confers a very meaningful role to the students, who construct their knowledge from certain guidelines, activities or scenarios designed by the teacher. Rather, through these activities, the teacher should encourage the students [64] to: be responsible for their own learning, and to develop skills of searching, selection, analysis and evaluation of information; to participate in activities that enable them to interchange experiences and opinions with their 
peers; to commit to processes of reflection about what to do, how to do it and what results to obtain, proposing specific actions for improvement; to interact with their environment in order to partake in it socially and professionally through activities such as projects, case studies and problem solving; and to develop autonomy, critical thinking, attitudes for collaboration, professional skills and the capacity for self-assessment.

These key issues help to determine how to organise the students' learning, how to assess them and how both the teacher and the students should act [82,83]. Given that these issues represent the three fundamental components of these methodologies, they formed the main focus of the present study. First is the organisational component, that is, the scenario or scenarios in which the teaching-learning processes are to be developed. In this study, these are determined as modes of organisation following classification [82,83]: theoretical classes; seminars/workshops; practice classes; tutorials; external practice/placements; and individual, independent and team work and study. The second comprises the procedural-technical component, formulated as methodological approaches, structured with [82,83]: participatory lectures, oral presentations of student projects, seminars, case studies, problem-based learning, portfolios, independent work, cooperative work, project-based learning, learning contracts and conceptual maps. The last component is evaluative, defined as systems of assessment $[82,83]$ : objective tests, long-answer tests, oral exams, assignments and projects, reports/notes on practice class sessions, tests on the performance of real tasks, self-assessment systems, observation techniques, portfolios and conceptual maps. For a detailed description of the modalities, methodological approaches and assessment systems, please see the study carried out by Crisol [62].

It is not easy to move from an approach based on teaching to one based on learning $[63,64,84]$. This change requires organisational changes, new infrastructures and teams, cooperative work by teachers, and an integrated study plan design [63,85]. All these changes need the motivation and commitment of teachers and students, as well as training programmes for the teachers $[85,86]$ since they continue to organise and plan around giving lectures.

This article aims to shed light on what pedagogical model is being used in the initial training of physical education teachers at the University of Granada from the perspective of the students. The objectives of the study are: (a) to learn the students' opinion on the use of active methodologies; (b) to describe the students' perception (frequency of use) and opinion (suitability of use) on the modes of organisation, methodological approaches and assessment systems that define the teaching-learning process; (c) to determine differences according to the sociodemographic, academic and relational variables of the participants: age, sex, gender, degree studied, level of satisfaction with the training received, meaning and utility of the new active methodologies, use of active methodologies by the teachers and the opinion of the students on the approach of the teaching-learning methodologies; and (d) to analyse correlations between the variables studied.

Lastly, we aim to set up a structural equation model (SEM) in order to estimate the possible effects or relations between the different constructs involved in the study, for the purpose of: (a) analysing the existing relations between the three fundamental components of the organisation of the students' learning: organizational and methodological approaches and assessment systems, as well as with their satisfaction; and (b) analysing the effect that including the students' opinion has on the approach of the teaching-learning methodologies (modes of organisation, methodological approaches and assessment systems).

\section{Materials and Methods}

\subsection{Participants}

The population under study was made up of 3068 students, enrolled in the 2017-2018 academic year at the University of Granada (UGR) (UGR Statistics, 2018) in the degrees of Sport and Physical Activity Science (CAFD) $(\mathrm{N}=921)$, of whom 232 were women and 689 were men, and Primary Education (CE) $(\mathrm{N}=2147)$, with 1277 women and $870 \mathrm{men}$, of whom 170 specialised in physical education (CEPEF) (Comprehensive Student Manage- 
ment System, SIGA, 2017-2018). We used simple random probability sampling [87] to select the participants, producing a total sample of 303 students: 145 from CAFD and 158 from CEPEF. The sociodemographic, academic and relational data of the sample are presented in Table 1: student knowledge, use, satisfaction and opinion on the active methodologies.

Table 1. Sociodemographic, academic and relational data of the 303 students evaluated.

\begin{tabular}{|c|c|c|c|}
\hline Variables & & CAFD $(N=145)$ & CEPEF $(N=158)$ \\
\hline \multirow{3}{*}{ Age } & 18-22 years & $129(89 \%)$ & $106(67.1 \%)$ \\
\hline & $23-27$ years & $11(7.6 \%)$ & $35(22.2 \%)$ \\
\hline & Over 28 years & $5(3.4 \%)$ & $17(10.8 \%)$ \\
\hline \multirow{3}{*}{ Sex } & Female & $41(28.3 \%)$ & $124(78.5 \%)$ \\
\hline & Male & $104(71.7 \%)$ & $34(21.5 \%)$ \\
\hline & Other & $0(0 \%)$ & $0(0 \%)$ \\
\hline \multirow{3}{*}{ Gender } & Woman & $41(28.3 \%)$ & $124(78.5 \%)$ \\
\hline & Man & $104(71.7 \%)$ & $34(21.5 \%)$ \\
\hline & Other & $0(0 \%)$ & $0(0 \%)$ \\
\hline \multirow{4}{*}{ Academic year } & 1 st & $30(20.7 \%)$ & $35(22.2 \%)$ \\
\hline & 2 nd & $42(29.0 \%)$ & $41(25.9 \%)$ \\
\hline & $3 r d$ & $45(31.0 \%)$ & $49(31.0 \%)$ \\
\hline & 4 th & $28(19.3 \%)$ & $33(20.9 \%)$ \\
\hline \multirow{2}{*}{ Work } & Yes & $28(19.3 \%)$ & $33(20.9 \%)$ \\
\hline & No & $116(80.7 \%)$ & $125(79.1 \%)$ \\
\hline \multirow{2}{*}{ Meaning and use of the active methodologies } & Yes & $80(55.2 \%)$ & $85(55.8 \%)$ \\
\hline & No & $65(44.8 \%)$ & $72(44.2 \%)$ \\
\hline \multirow{3}{*}{ Use of active methodologies by their teachers } & Yes & $128(88.3 \%)$ & $117(74.1 \%)$ \\
\hline & No & $17(11.7 \%)$ & $41(25.9 \%)$ \\
\hline & None & $0(0 \%)$ & $2(1.3 \%)$ \\
\hline \multirow{3}{*}{ Level of satisfaction with training received } & Not very & $19(13.1 \%)$ & $55(34.8 \%)$ \\
\hline & Quite & $97(66.9 \%)$ & $85(53.8 \%)$ \\
\hline & Very & $29(20 \%)$ & $16(10.1 \%)$ \\
\hline \multirow{2}{*}{ Opinion of methodological approach } & Yes & $69(47.6 \%)$ & $66(41.8 \%)$ \\
\hline & No & $76(52.4 \%)$ & $92(58.2 \%)$ \\
\hline
\end{tabular}

Note: CAFD = Degree of Sport and Physical Activity Science; CEPEF = Degree of Primary Education, specialising in physical education.

Most of the participants knew the meaning and utility of active methodologies (CAFD $\mathrm{N}=80$; CEPEF $\mathrm{N}=85$ ), stating that their teachers used them (CAFD $\mathrm{N}=128$; CEPEF $N=117$ ) and that their opinion was included in planning the teaching-learning methodologies (CAFD N = 69; CEPEF $N=66$ ). Furthermore, most students stated that they were quite or very satisfied with the training received (CAFD $N=126$; $C E P E F ~ N=101$ ).

\subsection{Design of the Study and Instruments}

This was a quantitative study with a cross-sectional and descriptive approach. Using an exploratory, descriptive and comparative research model, it explored the opinion of CAFD and CEPEF university students on the use of active methodologies. It described the perception of these two groups of the different modes of organisation, methodological approaches and assessment systems.

The study was developed within the framework of an analytic-synthetic method, with its starting point being the use of the questionnaire as a research instrument to approximate to reality in an objective and generalisable way.

We used the questionnaire "Opinion y Perception de los estudiantes sobre el uso de metodologías activas en la Universidad de Granada (OPEUMAUGR)" ("Opinion and Perception of students on the use of active methodologies in the University of Granada") [62,88] comprising 92 items and divided into two parts. The first part, which evaluated "Opinion 
on active methodologies", is made up of 43 items in 4 factors: methodological redevelopment (Factor I) (12 items), which analysed the actions that determined the methodological change in the university; use of active methodologies (Factor II) (9 items), which evaluated how the active methodologies were put into practice; context in the university (Factor III) (4 items), which focused on the aspects that characterised the habitual teaching-learning process; and context in the university classrooms (Factor IV) (8 items), which referred to aspects characterising the teaching in the university classrooms. It uses a four-point Likert-type scale: 1, "Completely disagree", 2 "Disagree", 3 "Agree" and 4 "Completely agree". The second part of the questionnaire, which analysed "Perception and opinion on the teaching-learning process", had 60 items divided into three dimensions: modes of organisation (14 items), methodological approaches (22 items) and sssessment systems (22 items). For "Frequency of use (perception)", the following response scale was used: 1 "Not at all", 2 "Little", 3 "Quite" and 4 "A lot". For "Suitability of use (opinion)", the response options were: 1 "Completely unsuitable", 2 "Not very suitable", 3 "Suitable" and 4 "Very suitable".

The instrument presented adequate psychometric properties, with values in the normed fit index (NFI) of 0.894, Tucker-Lewis index (TLI ) of 0.810, comparative fit index (CFI) of 0.848 and root mean square of residuals (RMSR) of 0.066 , which indicate an adequate fit of the instrument and an acceptable model [89,90], and a Cronbach's alpha coefficient of 0.920 , with a reliability level of $95 \%(p \leq 0.05)$ for the global scale, being 0.899 for the participants of this study $[62,91]$.

\subsection{Procedure}

To ensure fidelity and responsible research, the study followed the ethical considerations established by the ethics committee of the research team's university ( $\left.n^{\circ} 192 / C E I H / 2020\right)$. The study was made up of the following phases. First, the sample was determined and the selection made. Then a meeting was held with the teachers of the degree courses to gain access to the sample. The teachers gave permission for the study to go ahead, which enabled us both to select the sample and to create and complete the instrument with the consequent informed consent of the participants.

In the second phase, which was accessing different classrooms, the researchers informed the students about the study objectives and the voluntary and anonymous nature of participation. They explained the procedure to access the questionnaire online on Google Forms, and they handed out in writing the access link and numerical password valid for a single use. Subsequently, they read out the instructions-also included on the questionnaire itself-for completing the questionnaire and potential doubts were resolved. The students who wished to fill out the questionnaire had one week to do so.

\subsection{Data Analysis}

For the data analysis, the IBM SPSS version 26 (IBM, Madrid, Spain) and IBM SPSS Amos version 24 (IBM, Madrid, Spain) statistical packages were used. First, on the study objectives, we carried out descriptive (mean and standard deviation) and frequency analyses to characterise the sample and the opinion of the students from the area of physical education (CAFD and CEPEF) about active methodologies. Second, we applied normality and homoscedasticity tests to the sample, which allowed us to proceed with parametric statistics. Third, we calculated the Pearson correlation to find out the existing relation between the different factors that measure the opinion on active methodologies. Then, in order to study the comparisons between groups, we did a $t$-test for independent samples and a univariate ANOVA with the Bonferroni multiple comparisons test, in order to define between which groupings significant differences were observed according to the variables studied. Lastly, we used a structural equation model to estimate the effects or relations between the different constructs involved in the study, employing the IBM SPSS Amos version 24 program. 


\section{Results}

\subsection{Opinion on Active Methodologies}

The descriptive results of the students' opinions of active methodologies revealed that the highest degree of agreement occurred in the use of active methodologies (Factor II) $(\mathrm{M}=3.60, \mathrm{SD}=0.656)$ and context in the university (Factor III) $(\mathrm{M}=2.92, \mathrm{SD}=0.491)$. In contrast, they showed the least degree of agreement in Factor IV $(\mathrm{M}=2.72, \mathrm{SD}=0.354)$, related to the context in the university classrooms and Factor $\mathrm{I}(\mathrm{M}=2.68, \mathrm{SD}=0.342)$, concerning methodological renewal.

The correlation analysis showed that there was a positive and significant association $(p<0.01)$ between the responses on the use of active methodologies (Factor II) and methodological redevelopment (Factor I) $(\mathrm{r}=0.297)$. A positive and significant $(p<0.01)$ relation was found between the responses on the context in the university (Factor III) and methodological renewal (Factor I) $(\mathrm{r}=0.485)$ and the use of active methodologies (Factor II) $(r=0.176)$. Similarly, a direct and significant $(p<0.01)$ relation was also found between the responses concerning the context in the university classrooms (Factor IV) and methodological renewal (Factor I) $(r=0.497)$, the responses obtained on the use of active methodologies (Factor II) $(r=0.229)$ and the context in the university (Factor III) $(r=0.807)$.

No differences were found in the students' opinions as a function of age, and only marginally significant differences in Factor III according to sex and gender: $\mathrm{t}(300)=-1.964$; $p=0.05$. In this case, the women-who identified with the female gender-showed a greater degree of agreement with the questionnaire statements referring to the context in the university $(\mathrm{M}=3.03, \mathrm{SD}=0.526)$, compared to the men $(\mathrm{M}=2.91, \mathrm{SD}=0.541)$.

Statistically significant differences were observed in Factor II as a function of which degree the students were studying $(\mathrm{t}(231.715)=1.989 ; p<0.05)$ with the CAFD students $(M=2.68, S D=0.404)$, showing a higher degree of agreement with the questionnaire statements referring to the use of active methodologies, in comparison with the CEPEF students $(\mathrm{M}=2.53, \mathrm{SD}=0.818)$.

Regarding whether the students knew the meaning and utility of active methodologies, statistically significant differences were found in the opinions referring to Factor II $(\mathrm{t}(298)=2.437 ; p<0.05)$ and in total $(\mathrm{t}(296)=2.321 ; p<0.05)$. The students that knew the meaning and utility of the active methodologies showed a greater degree of agreement $\left(\mathrm{M}_{\text {Yes }}=3.04, \mathrm{SD}=0.471 \mathrm{vs} . \mathrm{M}_{\mathrm{No}}=2.73, \mathrm{SD}=0.335\right)$ with the questionnaire statements referring to the context in the university, and also showed, in general, a greater degree of agreement with the statements on active methodologies $\left(\mathrm{M}_{\text {Yes }}=2.79, \mathrm{SD}=0.324\right.$ vs. $\left.\mathrm{M}_{\mathrm{No}}=2.70, \mathrm{SD}=0.319\right)$. With respect to the use of active methodologies by their teachers, statistically significant differences were obtained in Factors I $(\mathrm{t}(78.138)=2.740 ; p<0.01)$, II $(\mathrm{t}(103.462)=2.393 ; p<0.05)$ and III $(\mathrm{t}(71.645)=2.470 ; p<0.05)$ and in total $(\mathrm{t}(74.643)=2.775$; $p<0.01)$. Once again, the students that showed that their teachers used active methodologies expressed a higher degree of agreement with the questionnaire statements on methodological renewal $\left(\mathrm{M}_{Y \mathrm{es}}=2.71, \mathrm{SD}=0.327 \mathrm{vs} . \mathrm{M}_{\mathrm{No}}=2.56, \mathrm{SD}=0.380\right)$, use of active methodologies $\left(\mathrm{M}_{\text {Yes }}=2.64, \mathrm{SD}=0.678\right.$ vs. $\left.\mathrm{M}_{\mathrm{No}}=2.44, \mathrm{SD}=0.529\right)$ and context in the university $\left(\mathrm{M}_{\mathrm{Yes}}=2.96, \mathrm{SD}=0.446\right.$ vs. $\left.\mathrm{M}_{\mathrm{No}}=2.75, \mathrm{SD}=0.622\right)$, as well as in general on the active methodologies ( $\left.\mathrm{M}_{Y e s}=2.78, \mathrm{SD}=0.291 \mathrm{vs} . \mathrm{M}_{\mathrm{No}}=2.64, \mathrm{SD}=0.373\right)$.

According to the students' level of satisfaction with the training received, statistically significant differences were only obtained in Factor $\mathrm{I}(\mathrm{F}(24,278)=8.517 ; p<0.001)$ and in total $(\mathrm{F}(52,247)=4.362 ; p<0.01)$. The students who were quite $(\mathrm{M}=2.66, \mathrm{SD}=0.323)$ or very satisfied $(\mathrm{M}=2.87, \mathrm{SD}=0.384)$ with the training received showed a higher degree of agreement with the questionnaire statements that referred to the methodological redevelopment, compared to those students who were a little $(\mathrm{M}=2.55, \mathrm{SD}=0.367)$ or not very satisfied $(M=2.54, S D=0.000)$. Similarly, the students who were very satisfied $(\mathrm{M}=2.88, \mathrm{SD}=0.341)$ with the training received showed a higher degree of agreement with the questionnaire statements on active methodologies, in comparison with the students who were a little satisfied $(M=2.66, S D=0.384)$. 
Taking into consideration the opinion of the students in the planning of the teachinglearning methodologies), statistically significant differences were seen in Factors I $(t(286.454)$ $=4.637 ; p<0.001), \mathrm{III}(\mathrm{t}(297.976)=1.725 ; p<0.05)$ and in total $(\mathrm{t}(294.987)=3.325 ; p<0.01)$. The students who affirmed that their teachers took their opinion into account when setting out the teaching-learning methodologies were more in agreement with the statements referring to methodological redevelopment $\left(\mathrm{M}_{\mathrm{Yes}}=2.78, \mathrm{SD}=0.313 \mathrm{vs} . \mathrm{M}_{\mathrm{No}}=2.60, \mathrm{SD}=0.330\right)$ and context in the university $\left(\mathrm{M}_{\mathrm{Yes}}=2.98, \mathrm{SD}=0.436 \mathrm{vs} . \mathrm{M}_{\mathrm{No}}=2.87, \mathrm{SD}=0.529\right)$, as well as in general to the active methodologies $\left(\mathrm{M}_{\mathrm{Yes}}=2.82, \mathrm{SD}=0.278 \mathrm{vs} . \mathrm{M}_{\mathrm{No}}=2.70, \mathrm{SD}=0.332\right)$.

\subsection{Perception and Opinion on the Teaching-Learning Process}

The descriptive results of the students' perception (frequent use) and opinion (suitable use) regarding the three components of the teaching-learning process-organisational and methodological approaches, and assessment systems-are presented in Table 2. According to the students' perception, the organisational modalities frequently used by the teachers were theoretical classes (3.20) and group study and work (3.00), while the least used was individual self-directed study and work (1.81). However, according to the students, the ideal modalities were the tutorials (3.45), individual, self-directed study and work (3.24) and external practice (3.13).

The methodological strategies frequently used by their teachers were self-directed work (3.24) and cooperative work (3.05), both being considered ideal by the students (3.14 and 3.42, respectively), along with project-oriented work (3.11). With respect to the assessment methods, the students indicated assignments and projects (3.18) and real and/or mock task-performance tests (3.04), with the one scoring the highest as the most suitable being assignments and projects (3.08).

As a function of degree studied, statistically significant differences were found in the perception and opinion of the organisational modalities (Table 3). The CEPEF students revealed that they had a more frequent use of seminars/workshops, while the CAFD students used tutorials the most. According to their opinion, differences were observed in the seminars/workshops, practice classes, tutorials and individual, self-directed study and work. The CEPEF students considered all these modalities except tutorials to be more ideal.

The degree studied also proved to be discriminating in the perception and opinion on methodological strategies (Table 4). The CAFD students perceived a greater use of presentations, cooperative work, project-based learning and learning contracts, whereas the CEPEF students indicated that participatory master lectures, seminars and portfolios were used more often. According to the CEPEF students' opinion, participatory master lectures, seminars, cooperative work and project-oriented learning were more suitable, while the CAFD students responded that presentations and learning contracts were more appropriate.

Lastly, with respect to the perception and opinion on the assessment systems, statistically significant differences were also observed according to the degree studied (Table 5). The CAFD students perceived greater use of oral tests, assignments and projects, taskperformance tests, self-assessment systems and observation techniques, whereas the CEPEF students only indicated using short-answer tests frequently. Regarding their opinions, the CAFD students considered oral tests, assignments and projects, real and/or mock taskperformance tests, observation techniques and conceptual maps to be the most suitable. For their part, the CEPEF students opined that portfolios were the most suitable. 
Table 2. The students' perception (frequent use) and opinion (suitable use) on organisational modalities, methodological approaches and assessment methods $(\mathrm{N}=303)$.

\begin{tabular}{|c|c|c|c|c|}
\hline \multirow{2}{*}{ Organisational Modalities } & \multicolumn{2}{|c|}{ Perception } & \multicolumn{2}{|c|}{ Opinion } \\
\hline & $\mathbf{M}$ & SD & $\mathbf{M}$ & SD \\
\hline Theoretical classes & 3.20 & 0.776 & 2.90 & 0.832 \\
\hline Seminars/Workshops & 2.28 & 0.937 & 2.85 & 0.916 \\
\hline Practice classes & 2.25 & 1.018 & 2.95 & 0.926 \\
\hline Tutorials & 2.95 & 0.935 & 3.45 & 0.789 \\
\hline External practice & 2.78 & 0.984 & 3.13 & 0.881 \\
\hline Individual, self-directed study and work & 1.81 & 0.991 & 3.24 & 0.903 \\
\hline Group study and work & 3.00 & 0.916 & 3.05 & 0.807 \\
\hline \multicolumn{5}{|l|}{ Methodological Approaches } \\
\hline Participatory master lecture & 2.82 & 0.864 & 2.93 & 0.872 \\
\hline Presentation by students & 2.64 & 0.960 & 2.91 & 0.934 \\
\hline Seminars & 2.22 & 0.910 & 2.82 & 0.888 \\
\hline Case studies & 2.10 & 0.907 & 2.89 & 0.911 \\
\hline Problem-based learning & 2.24 & 0.941 & 3.13 & 0.800 \\
\hline Portfolio & 2.28 & 1.013 & 2.66 & 1.532 \\
\hline Self-directed work & 3.24 & 0.756 & 3.14 & 0.779 \\
\hline Cooperative work & 3.05 & 0.873 & 3.42 & 1.379 \\
\hline Project-based learning & 2.26 & 0.923 & 3.11 & 0.835 \\
\hline Learning contract & 2.24 & 1.017 & 2.90 & 0.921 \\
\hline Conceptual maps & 2.74 & 1.061 & 2.91 & 0.956 \\
\hline \multicolumn{5}{|l|}{ Assessment Methods } \\
\hline Objective tests & 2.76 & 0.861 & 2.66 & 1.013 \\
\hline Short-answer tests & 2.91 & 0.810 & 2.70 & 0.949 \\
\hline Long-answer, development tests & 2.56 & 0.915 & 2.59 & 1.079 \\
\hline Oral tests & 2.69 & 0.952 & 2.14 & 1.009 \\
\hline Assignments and projects & 3.18 & 0.825 & 3.08 & 0.857 \\
\hline Practice reports/notes & 2.87 & 0.863 & 2.55 & 0.957 \\
\hline Real or mock task-performance tests & 3.04 & 0.844 & 2.53 & 1.012 \\
\hline Self-assessment systems (oral, written, individual, group) & 2.85 & 0.889 & 2.37 & 1.008 \\
\hline Observation techniques & 2.89 & 0.856 & 2.44 & 0.991 \\
\hline Portfolio & 2.58 & 0.950 & 2.22 & 0.998 \\
\hline Conceptual maps & 2.79 & 0.956 & 2.59 & 1.035 \\
\hline
\end{tabular}

Note: $\mathrm{M}=$ mean; $\mathrm{SD}=$ standard deviation.

Table 3. Comparison of the perception and opinion on the organizational modalities as a function of degree studied.

\begin{tabular}{|c|c|c|c|c|c|c|}
\hline \multirow{3}{*}{ Organisational Modalities } & \multicolumn{3}{|c|}{ Perception } & \multicolumn{3}{|c|}{ Opinion } \\
\hline & CAFD & CEPEF & \multirow{2}{*}{$\mathbf{t}$} & CAFD & CEPEF & \multirow{2}{*}{$\mathbf{t}$} \\
\hline & M(SD) & M(SD) & & M(SD) & M(SD) & \\
\hline Theoretical classes & $3.13(0.815)$ & $3.27(0.735)$ & -1.554 & $2.95(0.834)$ & $2.85(0.831)$ & 1.072 \\
\hline Seminars/Workshops & $2.15(0.996)$ & $2.40(0.867)$ & $-2.315^{*}$ & $2.69(0.995)$ & $3.00(0.814)$ & $-2.919^{* *}$ \\
\hline Practice classes & $2.27(1.079)$ & $2.22(0.962)$ & 0.448 & $2.82(0.983)$ & $3.08(0.856)$ & $-2.414^{*}$ \\
\hline Tutorials & $3.22(0.916)$ & $2.72(0.889)$ & $4.824^{* * *}$ & $3.55(0.719)$ & $3.37(0.840)$ & 1.969 \\
\hline External teaching practice & $2.70(0.975)$ & $2.85(0.989)$ & -1.384 & $3.05(0.922)$ & $3.21(0.837)$ & -1.577 \\
\hline Individual, self-directed study and work & $1.86(1.022)$ & $1.77(0.964)$ & 0.759 & $3.08(0.943)$ & $3.39(0.843)$ & $-3.005 *$ \\
\hline Study and work in group & $3.08(0.953)$ & $2.94(0.879)$ & 1.325 & $3.13(0.749)$ & $2.99(0.852)$ & 1.491 \\
\hline
\end{tabular}

Note: CAFD = Degree of Sport and Physical Activity Science; CEPEF = Degree of Primary Education specialising in physical education;

$\mathrm{M}=$ mean; $\mathrm{SD}=$ standard deviation; $\mathrm{t}=$ Student's $t$-test; ${ }^{*} p<0.05 ;{ }^{* *} p<0.01 ;{ }^{* * *} p<0.001$. 
Table 4. Comparison of the perception and opinion on the methodological approaches as a function of degree studied.

\begin{tabular}{|c|c|c|c|c|c|c|}
\hline \multirow{3}{*}{ Methodological Approaches } & \multicolumn{3}{|c|}{ Perception } & \multicolumn{3}{|c|}{ Opinion } \\
\hline & CAFD & CEPEF & \multirow{2}{*}{$\mathrm{t}$} & CAFD & CEPEF & \multirow{2}{*}{$\mathbf{t}$} \\
\hline & M(SD) & M(SD) & & M(SD) & M(SD) & \\
\hline Participatory master lecture & $2.67(0.859)$ & $2.96(0.847)$ & $-2.923^{* *}$ & $2.84(0.904)$ & $3.01(0.837)$ & $-2.923 * *$ \\
\hline Student presentation & $2.85(0.910)$ & $2.46(0.968)$ & $3.639 * * *$ & $2.95(0.905)$ & $2.88(0.960)$ & $3.639 * * *$ \\
\hline Seminars & $2.06(0.893)$ & $2.36(0.904)$ & $-2.919^{* *}$ & $2.70(0.966)$ & $2.93(0.799)$ & $-2.919 * *$ \\
\hline Case studies & $2.08(0.949)$ & $2.12(0.870)$ & -0.402 & $2.79(0.966)$ & $2.97(0.852)$ & -0.402 \\
\hline Problem-based learning & $2.28(0.936)$ & $2.20(0.947)$ & 0.802 & $3.04(0.895)$ & $3.21(0.696)$ & 0.802 \\
\hline Portfolio & $2.15(0.992)$ & $2.39(1.027)$ & $-2.086^{*}$ & $2.59(2.001)$ & $2.72(0.930)$ & -2.086 * \\
\hline Self-directed work & $3.25(0.785)$ & $3.23(0.731)$ & 0.232 & $3.19(0.780)$ & $3.09(0.777)$ & 0.232 \\
\hline Cooperative work & $3.22(0.854)$ & $2.89(0.864)$ & $3.289 * *$ & $3.39(0.815)$ & $3.44(1.739)$ & $3.289^{* *}$ \\
\hline Project-based learning & $2.48(0.930)$ & $2.06(0.872)$ & 4.004 & $3.04(0.890)$ & $3.16(0.781)$ & $4.004^{* * *}$ \\
\hline Learning contract & $2.40(1.101)$ & $2.09(0.915)$ & 2.563 & $2.92(0.942)$ & $2.88(0.905)$ & $2.563 *$ \\
\hline Conceptual maps & $2.67(1.060)$ & $2.80(1.062)$ & -1.116 & $2.97(0.922)$ & $2.85(0.985)$ & -1.116 \\
\hline
\end{tabular}

Note: $\mathrm{CAFD}=$ Degree of Sport and Physical Activity Science; CEPEF = Degree of Primary Education specialising in physical education; $\mathrm{M}=$ mean; $\mathrm{SD}=$ standard deviation; $\mathrm{t}=$ Student's $t$-test; ${ }^{*} p<0.05 ;{ }^{* *} p<0.01 ;{ }^{* * *} p<0.001$.

Table 5. Comparison of the perception and opinion on the assessment systems as a function of degree studied.

\begin{tabular}{|c|c|c|c|c|c|c|}
\hline \multirow{3}{*}{ Assessment Systems } & \multicolumn{3}{|c|}{ Perception } & \multicolumn{3}{|c|}{ Opinion } \\
\hline & CAFD & CEPEF & \multirow{2}{*}{$\mathbf{t}$} & CAFD & CEPEF & \multirow{2}{*}{$\mathbf{t}$} \\
\hline & M(SD) & M(SD) & & M(SD) & M(SD) & \\
\hline Objective tests & $2.53(1.035)$ & $2.78(0.982)$ & $-2.138 *$ & $2.74(0.967)$ & $2.77(0.756)$ & -0.271 \\
\hline Short-answer tests & $2.43(0.968)$ & $2.94(0.867)$ & $-4.737^{* * *}$ & $2.85(0.886)$ & $2.97(0.735)$ & -1.237 \\
\hline Long-answer, development tests & $2.51(1.021)$ & $2.66(1.126)$ & -1.258 & $2.55(0.914)$ & $2.56(0.920)$ & -0.095 \\
\hline Oral tests & $2.42(1.067)$ & $1.89(0.886)$ & $4.624^{* * *}$ & $2.90(0.928)$ & $2.51(0.938)$ & $3.612 * * *$ \\
\hline Assignments and projects & $3.28(0.849)$ & $2.91(0.828)$ & $3.841^{* * *}$ & $3.37(0.760)$ & $3.02(0.848)$ & $3.738^{* * *}$ \\
\hline Practice reports/notes & $2.53(0.992)$ & $2.56(0.927)$ & -0.312 & $2.91(0.886)$ & $2.84(0.844)$ & 0.723 \\
\hline Real and/or mock task-performance tests & $2.88(0.963)$ & $2.22(0) 953$. & $5.966^{* * *}$ & $3.21(0.818)$ & $2.89(0.841)$ & $3.330 * *$ \\
\hline Self-assessment systems & $2.56(1.012)$ & $2.20(0.976)$ & $3.138^{* *}$ & $2.83(0.886)$ & $2.87(0.894)$ & -0.423 \\
\hline Observation techniques & $2.69(0.936)$ & $2.22(0.988)$ & $4.213^{* * *}$ & $3.01(0.862)$ & $2.78(0.840)$ & $2.329 *$ \\
\hline Portfolio & $2.15(1.010)$ & $2.29(0.986)$ & -1.219 & $2.43(0.995)$ & $2.70(0.892)$ & $-2.458 *$ \\
\hline Conceptual maps & $2.56(1.047)$ & $2.61(1.027)$ & -0.360 & $2.90(0.966)$ & $2.68(0.938)$ & 1.970 \\
\hline
\end{tabular}

Note: CAFD = Degree of Sport and Physical Activity Science; CEPEF = Degree of Primary Education specialising in physical education; $\mathrm{M}=$ mean; $\mathrm{SD}=$ standard deviation; $\mathrm{t}=$ Student's $t$-test; ${ }^{*} p<0.05 ;{ }^{* *} p<0.01 ;{ }^{* * *} p<0.001$. Results derived from the structural equation model (SEM).

In respect to the structural equation model (SEM), used to estimate the effects or relations between the different constructs involved in the study, a path analysis was carried out, with the following observable variables: Opinion (OP); Satisfaction (STF); Perception Modalities (PMO); Opinion Modalities (OMO); Perception Methodological Approaches (PMA); Opinion Methodological Approaches (OMA); Perception Assessment Systems (PAS); and Opinion Assessment Systems (OAS).

The suitability tests of the data for preparing the SEM confirmed their univariate normality $[90,91]$. The model evaluation results indicated a good overall fit in all the indices. A chi-squared test gave a significant associated $p$-value $(\chi 2=801,248 ; \mathrm{df}=14$; $p=0.001)$. The comparative fit index (CFI) presented a value of 0.945 . The NFI value (0.917) was higher than the recommended value of 0.90 . The incremental fit index (IFI) value also obtained acceptable values (0.920). Lastly, the root mean square error of approximation (RMSEA) value of 0.053 fit the established parameters [91-94].

The estimations established in the trajectory analysis had significant values, with a positive and significant bidirectional influence (Table 6): between PMA and PAS; between PMA and OMA; between PAS and OAS; between OMA and OAS; between PMO and PMA; between PMO and PAS; between OMA and OMO; and between OAS and OMO. There 
was also a positive and significant influence between PMA and OP and a negative and significant influence between PAS and OP.

Table 6. Parameter estimates of final model.

\begin{tabular}{|c|c|c|c|c|c|c|}
\hline \multicolumn{3}{|c|}{ Associations between Variables } & \multirow{2}{*}{$\begin{array}{c}\mathbf{R W} \\
0.133\end{array}$} & \multirow{2}{*}{$\begin{array}{c}\text { SE } \\
0.006\end{array}$} & \multirow{2}{*}{\begin{tabular}{|c|} 
CR \\
21.919
\end{tabular}} & \multirow{2}{*}{$\frac{p}{* * *}$} \\
\hline strategies_P & $<->$ & evaluation_P & & & & \\
\hline strategies_O & $<->$ & strategies_P & 0.021 & 0.003 & 6.721 & $* * *$ \\
\hline evaluation_O & $<->$ & evaluation_P & 0.051 & 0.004 & 12.695 & $* * *$ \\
\hline strategies_O & $<->$ & evaluation_O & 0.117 & 0.006 & 19.544 & $* * *$ \\
\hline Satisfaction & $<->$ & strategies_P & -0.010 & 0.007 & -1.442 & 0.149 \\
\hline strategies_O & $<->$ & Satisfaction & -0.007 & 0.007 & -0.964 & 0.335 \\
\hline Satisfaction & $<->$ & evaluation_P & 0.001 & 0.008 & 0.167 & 0.868 \\
\hline evaluation_O & $<->$ & Satisfaction & 0.014 & 0.008 & 1.760 & 0.078 \\
\hline modalities_P & $<->$ & strategies_P & 0.143 & 0.006 & 22.678 & $* * *$ \\
\hline modalities_P & $<->$ & evaluation_P & 0.100 & 0.005 & 18.213 & $* * *$ \\
\hline strategies_O & $<->$ & modalities_O & 0.155 & 0.007 & 23.031 & $* * *$ \\
\hline evaluation_O & $<->$ & modalities_O & 0.096 & 0.006 & 15.957 & $* * *$ \\
\hline Opinion & $<-$ & strategies_P & 0.068 & 0.030 & 2.265 & $* * *$ \\
\hline Opinion & $<-$ & evaluation_P & -0.042 & 0.032 & -1.330 & $* * *$ \\
\hline
\end{tabular}

Note: RW = regression weights; $\mathrm{SE}$ = standard error; $\mathrm{CR}$ = critical radio; $\mathrm{SRW}$ = standardised regression weights $* * * p<0.001$.

The path analysis graphically brought together the associations between the study variables (Figure 1). The main constructs were PMO, OMO, PMA, OMA, PAS and OAS, with relations of three fundamental components on the organisation of the students' learning being established between the three types of perceptions and opinions (organisational modalities, methodological approaches and assessment systems), and in turn between the perception and opinion of each component of students' learning organisation. The opinion (OP) (when the teachers include the opinion of the students in the planning of the teaching-learning methodologies) was positively influenced by the PMA and negatively by the PAS. A relation was also revealed between the STF and the OMA and OAS. These results indicate that the perception the students held of the methodological approaches that their teachers used frequently was correlated with the opinion (suitable use) they held on these methodological approaches. In other words, the perception that the students stated having could arise from their opinion or vice versa.

Moreover, the students' perception of the frequent use of methodological strategies by their teachers was affected when the teachers took their opinion into account when planning the teaching and learning process. In contrast, taking the students' opinion into account when determining the planning of the teaching-learning process did not affect their perception of the assessment systems or methods. These results show that the students' opinion on the planning of the teaching-learning processes only had an influence on the methodological approaches and not on the assessment methods that the teachers would put into practice.

The SEM also showed that when the students' opinion was taken into account in the planning of the teaching-learning process, their satisfaction regarding the teaching increased. 


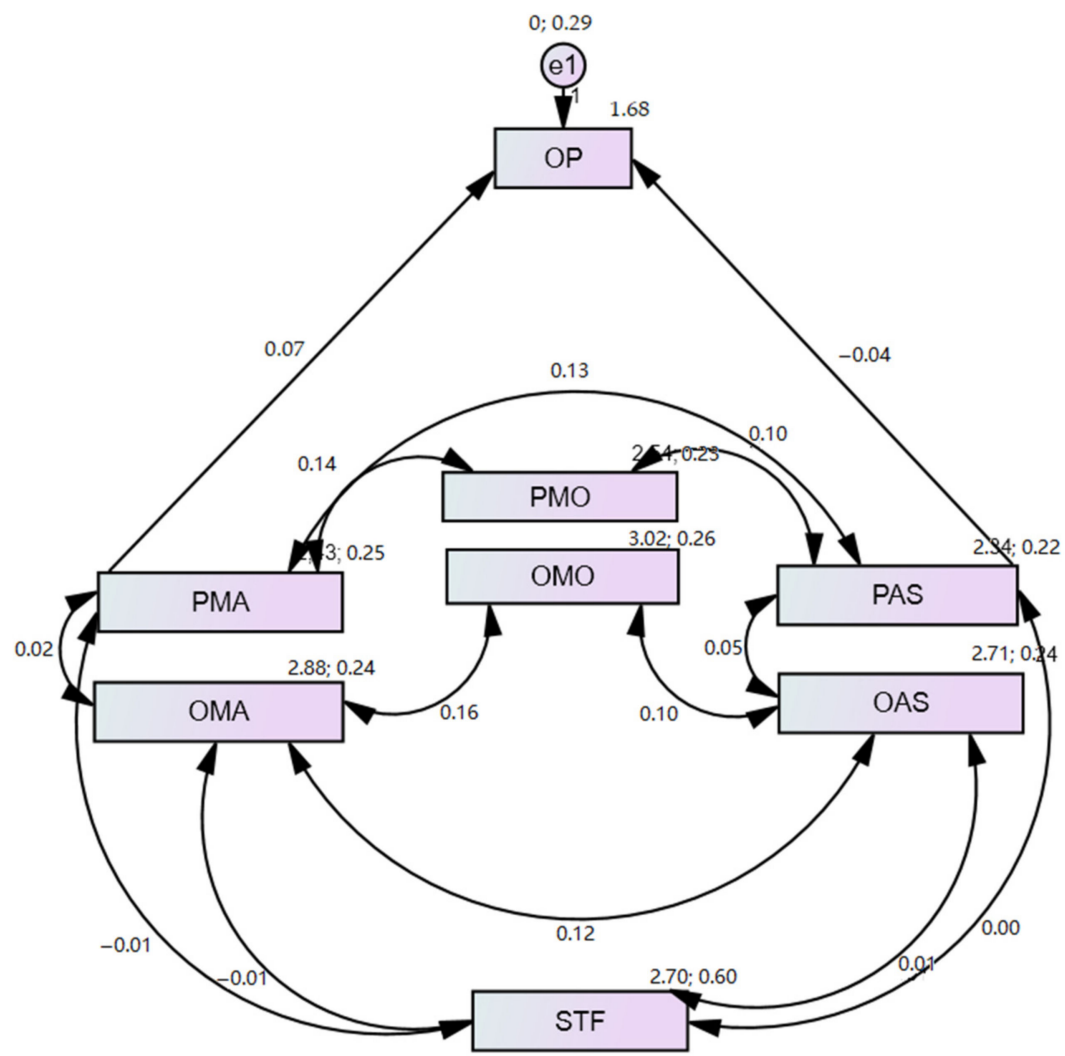

Figure 1. Estimates of the structural equation model. Note: OP = Opinion; STF = Satisfaction; $\mathrm{PMO}=$ Perception Modalities; $\mathrm{OMO}=$ Opinion Modalities; PMA = Perception Methodological Approaches; OMA = Opinion Methodological Approaches; PAS = Perception Assessment Systems; OAS = Opinion Assessment Systems.

\section{Discussion}

The implementation of active methodologies offers many possibilities for achieving quality physical education. There is often a "gap" between the theoretical evidence given in the physical education training guidelines and its subsequent use in reality, which leads to a failure to achieve a conscious and rational application of the different physical exercises. Some habits and beliefs about physical activity are distorted and incorrect. This could bring about not only a reduction in participation in physical activity programmes but also cause injuries due to excessive use and poor habits among those who undertake physical activity $[95,96]$. In this study, we have looked at how the students consider active methodologies, with the aim of raising the awareness of the scientific community of the potential of the combination of active methodologies (organisational modalities, methodological approaches and assessment systems) in the teaching and learning process in the field of physical education.

The study shows the perception and opinion of CAFD and CEPEF students on the use of active methodologies. These results can help the university community to improve their teaching practice, since it contributes to knowledge on the perception (frequency of use) and opinion (suitability of use) that students have of the teaching and learning processes. Moreover, through this study, we have tested a structural equation model for analysing the predictive relations between the three fundamental components (organisational modalities, methodological approaches and assessment systems) and with the satisfaction and opinion variable of the students in the approach and planning of the teaching-learning methodologies, with the intention of determining how to organise and assess the students' learning, and the performance both of the teacher and the students.

Regarding the opinion on active methodologies, in general, the students, and in particular the CAFD students, are in agreement with all the aspects referring to the use of 
active methodologies. Furthermore, the highest standard deviation value was concentrated in the opinions shown, which had greatest consolidation in the response option. In this case, they agreed that: the active methodologies focused more on the learning of the student than the teaching of the teacher; they enabled the student to confront real problems similar to those that exist in professional teaching; and they encouraged student participation in the classroom as well as content interdisciplinarity. It was also suggested that the use of active methodologies heightened the acquisition of self-directed learning; or that the use of these methodologies fostered group work and learning among the students.

These results are in line with those from other studies that show that students in general have a positive attitude toward active learning, particularly when the students are informed about the use of active methods [54-58,88]. Ventosa [97] obtains similar results, highlighting that the use of active methods promotes analysis and reflection in the students, contributing to their playing an active role in knowledge acquisition. Perhaps the main difficulty in applying these methods is the large number of students per class, which hinders the undertaking of active methodologies $[5,45,55,58,98,99]$.

The results revealed a relation between methodological redevelopment regarding the use of active methodologies and suitability for putting them into practice both at the university and classroom level. This leads to us to determine that, from the students' point of view, in the area of physical education, different methodological adaptations are being carried out in the teaching and learning process as a response to the demands and needs of implementing active methodologies.

However, it cannot be said that there was unanimous perception and opinion in all the respondents, as statistically significant differences were found in all the variables studied, except age and sex. This indicates that, in the students' opinions, the following have an effect: whether they know the meaning and utility of employing active methodologies; whether or not their teachers use active methodologies; their level of satisfaction with the training received; and, of course, whether the teachers take into account their opinion when it comes to determining the planning of the teaching-learning methodologies.

From this perspective, it is worth reflecting on the importance of methodological renewal, both at the university level as a whole and at the classroom level, in favour of the use of active methodologies, since these measures will contribute to offering a more robust and all the more satisfactory training for the students. This is in line with the argument made by Pérez-López et al. [100] that an ever higher percentage of physical education teachers are trying to introduce methodological adaptation to the teaching-learning process in respond to new social needs and demands, as occurs in their considering student opinion when setting out methodologies. Although there has not yet been complete implementation in the classroom, there is progress toward quality physical education, which upholds the use of more open methodologies and entails the active participation of students in their learning - contextualised and competence based-progressively leaving behind the more traditional models [12,19-21,52-55,100].

With respect to the students' perception (frequent use) of the learning process, they observe that their teachers made use of different organisational modalities, methodological strategies and assessment systems that favour the use of active methodologies.

In terms of organisation, the students perceive a varied use of the different modalities, mainly with a continued predominance of theoretical classes. Along with these, the CAFD students stated that there was greater use of tutorials and group study and work, while the CEPEF students observed a higher use of seminars.

Concerning methodological strategies, it is noteworthy that though the use of participatory master lectures was still perceived, it was no longer the principal methodological strategy. In this case, both the CEPEF and the CAFD students indicated that their teachers used self-directed work to a greater extent; the latter also added the use of cooperative work. In the perception of assessment systems, both sets of degree students perceived the use of assignments and projects. However, there were discrepancies, since the CAFD students also identified real or mock task-performance tests and observation techniques, 
while the CEPEF students highlighted a greater use of short-answer tests and assignments and projects.

Faced with these data, in accordance with the views of some authors [50], we can still discern certain scepticism on the part of the teachers of the subject, who have feelings of fear or insecurity when it comes to confronting the challenge of changing to a more open and diverse teaching-learning model. Perhaps the uncertainty of giving up some of their responsibility in the intervention, and the lack of experience and/or the need for a specific training of the teachers to implement them, partly explain this feeling of rejection. This conclusion may lead some teachers to not apply active methodologies or to apply them in an indecisive way along with a more traditional methodology (mixed methodology) [49,50].

It is worth noting that the students' perception and opinion coincide with respect to different modalities, methodological strategies and assessment systems for learning physical education. Hence, the CAFD students were in agreement when indicating tutorials and group work as organisational modalities; self-directed work and cooperative work as methodological strategies; and assignments and projects as assessment systems [101,102]. The CEPEF students, however, identified a frequent and suitable use of seminars as organisational modalities, self-directed work as a methodological strategy and assignments and projects as an assessment system. These results are similar to those obtained in comparable studies $[13,45,48,60,96,97]$.

Regarding the predictive relations of the variables studied through the SEM, the structural model had a good fit. We were able to determine that the opinion (OMO, OMA and OAS), that is, the suitable use both of organisational modalities, methodological strategies and also assessment systems, could come to depend on the students' perception (PMO, PMA and PAS) (frequent use) of them. Dependence on the perception of the methodological approaches was also shown, as a function of whether the teachers considered the students' opinion in planning the teaching-learning methodologies. However, satisfaction was related neither to perception nor to the opinion of the methodological strategies or assessment systems. This was despite the fact that in different studies $[98,100,102,103]$, the application of an active methodology gains greater satisfaction for the subject.

The structural equation model also established that the frequent use of the modes of organisation, methodological approaches and assessment methods indicated by the students determined their evaluation of suitable use. Likewise, their opinion influenced their perception. Furthermore, the SEM estimated that the fact of taking the students' opinion into account in determining the teaching-learning processes affected their perception of the methodological approaches, but not of the assessment systems. This result is relevant because for an appropriate and complete transition from a methodology based on teaching to one based on fostering active learning, the teachers need to take their students' opinion into account $[62,64,76]$. Moreover, taking the students' opinion into account in the teaching-learning process brings about an increase in student motivation and satisfaction, due to the new opportunities and media of learning that they have at their disposal [72,73].

Nevertheless, it should be noted that this study has certain limitations. One is its crosssectional nature, since it only represents that sample in that moment. Additionally, the study was carried out only with students specialising in physical education and through simple random probability sampling. A longitudinal study with the total population could lead to obtaining data that could be assumed to be representative. Furthermore, the present structural equation model has some limitations, including the fact of having analysed the effect and relation of two of the studied variables (students' opinion of the teaching-learning methodology and satisfaction) without including the other variables. This means not offering the full verisimilitude of the SEM predictive power in comparing with the other variables. In future studies, it would be interesting to complete this analysis by including variables such as the degree studied, academic year, age and sex (gender), as well as carrying out a contrast between the students' perceptions and the pedagogical models implemented by the teachers. 


\section{Conclusions}

Modern education seeks to incorporate new teaching models, enabling a redevelopment of teaching methodologies that transform the learning process into meaningful experiences for the students, especially encouraging aspects such as reflection and active participation in classes [103]. Therefore, what is desired is an approach that enables the students to develop their skills; an approach in which they are the real protagonists, in place of the explicit teaching of teachers [104]. The teaching of physical education should introduce a process of constant change in the students' teaching practice, with continual transformations [105].

The content of these results show that the teachers are progressing toward a learningbased model, according to the perception and opinion of the students. Equally, given the lack of training that the teachers perceive, we should consider whether the implementation of these innovative proposals in the classroom is only due to a trend that is being carried out without taking into account the principles at the basis of physical education, or the impact on student learning [105]. As Zapatero-Ayuso [106] states, physical education "has educational models at its disposal that aim to attain greater student motivation, participation, autonomy and responsibility through the development of the subject's content". Some of these approaches are the Sport Education Model [107], the "Ludotechnical" Model of Sport Initiation, the Teaching Games for Understanding Model and Hellison's Model of Teaching Personal and Social Responsibility [108]. Therefore, physical education professionals should examine these models, designed for the subject, in order to guarantee the potential benefits of a student-centred intervention.

In light of the results, it is clear that physical education students require a break from traditional methodologies and demand new ways that will give them greater prominence. Moreover, there is no doubt that one of the aims of physical education today lies in responding to the needs of twenty-first century society [109]; the use of active methods is one of the ways of achieving this.

Finally, it should be stated that although a student-based methodology can attain certain benefits $[110,111]$, there is no one better or worse style, as they are all dependent on adopting a critical perspective according to the teaching context [112,113].

Author Contributions: E.C.M. and M.J.C.C. conceived the hypothesis of this study. E.C.M. and M.J.C.C. participated in data collection. E.C.M. and M.J.C.C. analysed the data. All authors contributed to data interpretation of statistical analysis. E.C.M. and M.J.C.C. wrote the paper. All authors have read and agreed to the published version of the manuscript.

Funding: This research received no external funding.

Institutional Review Board Statement: The study was conducted according to the guidelines of the Declaration of Helsinki, and approved by the Ethic Committee of University of Granada (protocol code 192/CEIH/2020 date 09 October 2020).

Informed Consent Statement: Informed consent was obtained from all subjects involved in the study.

Data Availability Statement: The data presented in this study are available on request from the corresponding author.

Conflicts of Interest: The authors declare no conflict of interest.

\section{References}

1. Vergara, J.J. Aprendo Porque Quiero: El Aprendizaje Basado en Proyectos (ABP), Paso a Paso; Ediciones SM: Madrid, Spain, 2017 ; p. 11.

2. García-Sanz, E.; Metodologías Activas y Participativas en Educación Física. Una Propuesta de Intervención. La Escuela de Superpoderes. Trabajo Fin de Grado, Universidad de Valladolid. 2019. Available online: http://uvadoc.uva.es/handle/10324/34814 (accessed on 24 October 2020).

3. Ruiz-Montero, P.J.; Baena-Extremera, A. Metodologías Activas en Ciencias del Deporte (V.II); Editorial Wanceulen: Sevilla, Spain, 2019.

4. Pellicer, I. NeuroEF La REVOLUCIÓN de la Educación Física Desde la NEUROCIENCIA; INDE: Barcelona, Spain, 2015. 
5. León-Díaz, O.; Martínez-Muñoz, L.F.; Santos-Pastor, M.L. Research analysis on the Project-based Learning in Physical Education. Rev. Electrónica Interuniv. Form. Profr. 2018, 21, 27-42. [CrossRef]

6. Kerrigan, J. Active learning strategies for the mathematics classroom. Coll. Teach. 2018, 66, 35-36. [CrossRef]

7. Nogueira, F.; Shigueo, E.; Abdala, H. Collaborative teaching and learning strategies for communication networks. Int. J. Eng. Educ. 2018, 34, 527-536.

8. Segura-Robles, A.; Fuentes-Cabrera, A.; Parra-González, M.E.; López-Belmonte, J. Effects on Personal Factors Through Flipped Learning and Gamification as Combined Methodologies in Secondary Education. Front. Psychol. 2020, 12, 1103. [CrossRef]

9. Syrmpas, I.; Digelidis, N.; Watt, A.; Vicars, M. Physical education teachers' experiences and beliefs of production and reproduction teaching approaches. Teach. Teach. Educ. 2017, 66, 184-194. [CrossRef]

10. Capel, S.; Bassett, S.; Lawrence, J.; Newton, A.; Zwozdiak-Myers, P. How trainee physical education teachers in England write, use and evaluate lesson plans. Eur. Phys. Educ. Rev. 2018, 25, 964-982. [CrossRef]

11. Manzano-Sánchez, D.; Conte-Marín, L.; Gómez-López, M.; Valero-Valenzuela, A. Applying the Personal and Social Responsibility Model as a School-Wide Project in All Participants: Teachers' Views. Front. Psychol. 2020, 11, 579. [CrossRef] [PubMed]

12. Kirk, D. Precarity and physical education. Revisa De Alesde. 2018, 9, 15-20. [CrossRef]

13. Fernández-Río, J.; Méndez-Giménez, A. El Aprendizaje Cooperativo: Modelo Pedagógico para la Educación Física. Retos Nuevas Tend. Educ. FísicaDeportes Y Recreación 2016, 29, 201-206.

14. Palermi, S.; Sacco, A.M.; Belviso, I.; Romano, V.; Montesano, P.; Corrado, B.; Sirico, F. Guidelines for Physical Activity-A Cross-Sectional Study to Assess Their Application in the General Population. Have We Achieved Our Goal? Int. J. Env. Res. Public Health 2020, 17, 3980. [CrossRef]

15. López, V.M.; Gea, J. Innovación, discurso y racionalidad en educación física. Revisión y prospectiva. Rev. Int. Med. Y Cienc. La Act. Física Y El Deporte 2010, 10, 245-270.

16. Cebrián-de-la-Serna, M.; Bartolomé-Pina, A.; Cebrián-Robles, D.; Ruiz-Torres, M. Estudio de los Portafolios en el Practicum: Análisis de un PLE-Portafolios. Relieve 2015, 21, 1-18. [CrossRef]

17. Bista, K. How to create a learning-centered ESL program. Engl. Spec. Purp. World 2011, 31, 1-13. [CrossRef]

18. McLean, M.; Gibbs, T. Twelve tips to designing and implementing a learner-centered curriculum: Prevention is better than cure. Med. Teach. 2010, 32, 225-230. [CrossRef] [PubMed]

19. Menachery, E.P.; Wright, S.M.; Howell, E.E.; Knight, A.M. Physicianteacher characteristics associated with learner-centered teaching skills. Med. Teach. 2008, 30, 137-144. [CrossRef] [PubMed]

20. Mostrom, A.; Blumberg, P. Does learning-centered teaching promote grade improvement? Innov. High. Educ. 2012, 37, 397-405. [CrossRef]

21. Prieto, L. La Enseñanza Universitaria Centrada en el Aprendizaje; Octaedro: Barcelona, Spain, 2008.

22. Brackin, M. Two-year college faculty and administrator thoughts about the transition to a learning-centered college. Community Coll. J. Res. Pr. 2012, 36, 179-190. [CrossRef]

23. Campbell, C. Learning-centered grading practices. Leadership 2012, 41, 30-33.

24. Hunt, L.; Chalmers, D. University Teaching in Focus: A Learning-Centred Approach; Routledge: Abingdon, UK, 2013.

25. Nitza, D. Learning-centered teaching and backward course design-From transferring knowledge to teaching skills. J. Int. Res. 2013, 9, 329-338. [CrossRef]

26. Sue, T. Student-centred learning: A humanist perspective. Teach. High. Educ. 2014, 19, $266-275$.

27. Schweisfurth, M. Learner-centred pedagogy: Towards a post-2015 agenda for teaching and learning. Int. J. Educ. Dev. 2015, 40, 259-266. [CrossRef]

28. Zabalza, M.A. Metodología docente. El espacio europeo de educación superior. ¿Hacia dónde va la Universidad Europea? Rev. Doc. Univ. 2011, 9, 75-98.

29. Tessier, J. Small-group peer teaching in an introductory biology classroom. J. Coll. Sci. Teach. 2007, 36, 64-69.

30. Armbruster, P.; Patel, M.; Johnson, E.; Weiss, M. Active learning and student-centered pedagogy improve student attitudes and performance in introductory biology. Education 2009, 8, 203-213. [CrossRef] [PubMed]

31. Roy, E.B.; McMahon, G.T. Videobased cases disrupt deep critical thinking in problem-based learning. Med. Educ. 2012, 46, 426-435.

32. Bruehl, M.; Pan, D.; Ferrer-Vinent, J. Desmystifying the chemistry literature: Building information literacy in first-year chemistry students trough student-centered learning and experiment design. J. Chem. Educ. 2014, 92, 52-57. [CrossRef]

33. Chen, J.; Zhou, J.; Sun, L.; Wu, Q.; Lu, H.; Tian, J. A new approach for laboratory exercise of pathophysiology in China based on student-centered learning. Adv. Physiol. Educ. 2015, 39, 116-119. [CrossRef]

34. Acaso, M. rEDUvolution: Hacer la Revolución en la Educación; Paidós: Barcelona, Spain, 2013.

35. Aranda, P.; Monleón, C. El aprendizaje basado en proyectos en Educación Física. Act. Física Y Deporte Cienc. Y Profesión 2016, 24, 53-66.

36. Bernal, M.C.; Martínez, M.S. Metodologías activas para la enseñanza y el aprendizaje. Rev. Panam. Pedag. 2009, 14, 101-106.

37. Carbonell, J. Pedagogías del Siglo XXI: Alternativas Para la Innovación Educativa; Octaedro: Barcelona, Spain, 2015.

38. Chiva, O.; Martí, M. Métodos Pedagógicos Activos y Globalizadores: Conceptualización y Propuestas de Aplicación; Graó: Barcelona, Spain, 2016. 
39. Fortea, M.A. Metodologías Didácticas Para la Enseñanza/Aprendizaje de Competencias; Unitat de Suport Educatiu de la Universitat Jaume I, Castellón de la Plana: Valencia, Spain, 2019. [CrossRef]

40. García, A. Otra Educación ya es Posible: Una introducción a las Pedagogías Alternativas; Litera: Madrid, Spain, 2017.

41. Johnson, L.; Adams, S.; Estrada, V.; Freeman, A. NMC Horizon Report: 2015 K-12 Edition; The New Media Consortium: Austin, TX, USA, 2015. Available online: http:/ / www.funciva.org/wpcontent/uploads/2016/11/Horizon-Repor-2015.pdf (accessed on 21 October 2020).

42. Melero, N.; Bernabéu, N. Metodologías Activas Para el Aprendizaje Competencial: Herramientas Para la Comunidad Educativa; Síntesis: Madrid, Spain, 2016.

43. Scott, C.L. El futuro del Aprendizaje 3 ¿Qué tipo de Pedagogías se Necesitan Para el siglo XXI? Investigación y Prospectiva en Educación; UNESCO: París, France, 2015. Available online: https://unesdoc.unesco.org/ark:/48223/pf0000243126_spa (accessed on 17 October 2020).

44. Zabala, A.; Arnau, L. Métodos para la Enseñanza de las Competencias; Graó: Barcelona, Spain, 2014.

45. Blázquez, D Métodos de Enseñanza en Educación Física: Enfoques Innovadores Para la Enseñanza de Competencias; Inde: Barcelona, Spain, 2014.

46. Castejón, F.J.; Santos, M.L. Percepciones y dificultades en el empleo de metodologías participativas y evaluación formativa en el Grado de Ciencias de la Actividad Física. Rev. Electrón. Int. Form. Profr. 2011, 14, 117-126.

47. Contreras, O.; Gutiérrez, D. El Aprendizaje Basado en Proyectos En Educación Física; Inde: Barcelona, Spain, 2017.

48. Fernández-Río, J. El ciclo del Aprendizaje Cooperativo: Una guía para implementar de manera efectiva el aprendizaje cooperativo en educación física. Retos 2017, 32, 264-269.

49. León-Díaz, O.; Arija-Mediavilla, A.; Martínez-Muñoz, L.F.; Santos-Pastor, M.L. Las metodologías activas en Educación Física. Una aproximación al estado actual desde la percepción de los docentes en la Comunidad de Madrid. Retos 2020, 38, 587-594.

50. León-Díaz, O.; Martínez-Muñoz, L.F.; Santos-Pastor, M.L. Gamificación en Educación Física: Un análisis sistemático de fuentes documentales. Rev. Ibero. Eval. Educ. 2018, 8, 110-124. [CrossRef]

51. Nielsen, A.; Romance, A.R.; Chinchilla, J.L. Los ambientes de aprendizaje como metodología activa promotora de la actividad física en Educación Infantil. Un estudio de caso. Retos 2020, 37, 498-504.

52. Quintero, L.E.; Jiménez, F.; Area, J. Más allá del Libro de Texto. La Gamificación Mediada con TIC Como Alternativa de Innovación en Educación Física. Retos 2018, 34, 343-348. [CrossRef]

53. Rubio, L.; Campo, L.; Sebastiani, E.M. Aprendizaje Servicio y Educación Física: Experiencias de Compromiso Social a Través de la Actividad Física y el Deporte; Inde: Barcelona, Spain, 2014.

54. Atienza, R.; Valencia-Peris, A.; Martos-García, D.; López-Pastor, V.M.; Devís-Devís, J. La percepción del alumnado universitario de educación física sobre la evaluación: Ventajas, dificultades y satisfacción. Movimento 2016, 22, 1033-1048. [CrossRef]

55. Dekker-Groen, A.; Van der Schaaf, M.; Stokking, K. A Teacher Competence Development Programme for Supporting Students' Reflection Skills. Teach. Teach. Theory Pr. 2013, 19, 150-171. [CrossRef]

56. Jungst, S.E.; Thompson, J.R.; Atchison, G.J. Academic controversy: Fostering constructive conflict in the classroom. J. Nat. Resour. Life Sci. Educ. 2003, 32, 36-42. [CrossRef]

57. National Association for Sport and Physical Education (NASPE) y American Heart Association (AHA)). Shape of the Nation Report: Status of Physical Education in the USA. 2012. Available online: https://www.shapeamerica.org/advocacy/son/2012 / upload/2012-Shape-of-Nation-full-report-web.pdf (accessed on 10 October 2020).

58. Qualters, D.M. Using Classroom Assessment Data to Improve Student Learning Classroom Assessment Guidebook; Northeastern University: Boston, MA, USA, 2001.

59. Almirall, L. Epic clans: Gamificando la educación física. Tándem 2016, 51, 67-73.

60. Fernández-Espínola, C.; Almagro, B.J.; Tamayo, J. Predicción de la intención de ser físicamente activo del alumnado de Educación Física: Un modelo mediado por la necesidad de novedad. Retos 2020, 37, 442-448.

61. Samuelowicz, K.; Bain, J.D. Identifying academics' orientatios to assessment practice. High. Educ. 2002, 43, 173-201. [CrossRef]

62. Crisol, E. Opinión y Percepción del Profesorado y de los Estudiantes Sobre el uso de las Metodologías Activas en la Universidad de Granada. Tesis Doctoral, Universidad de Granada. 2013. Available online: https://digibug.ugr.es/bitstream/handle/10481/ 23759/21224043.pdf?sequence=1\&isAllowed=y (accessed on 5 October 2020).

63. Crisol, E. Using Active Methodologies: The students'view. Procedia Soc. Behav. Sci. 2017, 237, $672-677$.

64. Crisol, E.; Romero, A.; Caurcel, M.J. Active Methodologies in Higher Education: Perception and Opinion as Evaluated by Professors and Their Students in the Teaching-Learning Process. Front. Psychol. 2020, 11, 1703. [CrossRef]

65. Crisol, E. Student and teacher. New roles in the university. J. Educ. Teach. Train. 2011, 2, 82-88.

66. Gijón Puerta, J.; Crisol Moya, E. La internacionalización de la Educación Superior. El caso del Espacio Europeo de Educación Superior. REDU 2012, 10, 389-414.

67. Lammers, W.J.; Murphy, J.J. A profile of teaching techniques used in the university classroom: A descriptive profile of a US public university. Act. Learn. High. Educ. 2002, 3, 54-67. [CrossRef]

68. Romero, M.A.; Crisol, E. Las guías de aprendizaje autónomo como herramienta didáctica de apoyo a la docencia. Esc. Abierta 2012, 15, 9-31.

69. Romero, M.A.; Crisol, E. El portafolio, herramienta de autoevaluación del aprendizaje de los estudiantes. Una experiencia práctica en la Universidad de Granada. Rev. Docen. Investig. 2011, 21, 25-50. 
70. Prince, M. Does active learning work? A review of the research. J. Eng. Educ. 2004, 93, 223-232. [CrossRef]

71. García, M.; Baena-Extremera, A. Motivación en Educación Física a través de diferentes metodologías didácticas. Profesorado 2017, 21, 387-402.

72. Álvarez-Rodríguez, M.D.; Bellido-Márquez, M.; Atencia-Barrero, P. Enseñanza artística mediante TIC en la educación secundaria obligatoria. Rev. Educ. Dist. 2019, 19, 59. [CrossRef]

73. Mat, N.S.; Abdul, A.; Mat, M.; Abdul, S.Z.; Nun, N.F.; Hamdan, A. An evaluation of content creation for personalised learning using digital ict literacy module among aboriginal students (MLICT-OA). Turk. Online J. Distance Educ. 2019, 20, 41-58. [CrossRef]

74. Nikolopoulou, K.; Akriotou, D.; Gialamas, V. Early reading skills in english as a foreign language via ict in greece: Early childhood student teachers' perceptions. Early Child. Educ. 2019, 47, 597-606. [CrossRef]

75. Cabero, J.; Barroso, J. Los escenarios tecnológicos en realidad aumentada (RA): Posibilidades educativas. Aula Abierta 2018, 47, 327-336. [CrossRef]

76. Exley, K.; Dennick, R. Enseñanza en Pequeños Grupos en Educación Superior; Narcea: Madrid, Spain, 2007.

77. López-Noguero, F. Metodología Participativa en la Enseñanza Universitaria; Narcea Ediciones: Madrid, Spain, 2007.

78. López-Pastor, V.M.; Castejón, J.; Sicilia-Camacho, A.; Navarro-Adelantado, V.; Webb, G. The process of creating a cross-university network for formative and shared assessment in higher education in Spain and its potential applications. Innov. Educ. Teach. Int. 2011, 48, 79-90. [CrossRef]

79. Rué, J. Enseñar en la Universidad; Narcea: Madrid, Spain, 2007.

80. Biggs, J. Calidad del Aprendizaje Universitario; Narcea: Madrid, Spain, 2005.

81. Gibbs, G. Learning in Teams: A Student's Guide; Oxford Brookes University: Oxford, UK, 1994.

82. De Miguel, M. Propuestas para la Renovación de las Metodologías Educativas en la Universidad; Secretaría General Técnica del MEC: Madrid, Spain, 2006.

83. De Miguel, M. Metodologías de Enseñanza y Aprendizaje Para el Desarrollo de Competencias: Orientaciones Para el Profesorado Universitario ante el Espacio Europeo de Educación Superior; Alianza: Madrid, Spain, 2009.

84. Heise, B.; Himes, D. The course council: An example of student-centered learning' educational innovation. Release 2010, 29, 343-345. [CrossRef]

85. De La Sablonnière, R.; Taylor, D.M.; Sadykova, N. Challenges of applying a student-centred approach to learning in the context of Education in Kyrgystan. Int. J. Educ. Dev. 2009, 29, 628-634. [CrossRef]

86. Maclellan, E. The significance of motivation in student-centred learning: A reflective case study. Teach. High. Educ. 2008, 13, 411-421. [CrossRef]

87. Hernández, R.; Fernández, C.; Baptista, P. Metodología de Investigación; McGraHill: Mexico City, Mexico, 2006.

88. León, M.J.; Crisol, E. Diseño de cuestionarios (OPPUMAUGR Y OPEUMAUGR): La opinión y la percepción del profesorado y de los estudiantes sobre el uso de las metodologías activas en la universidad. Profesorado 2011, 15, 271-298.

89. Timmerman, M.E.; Lorenzo-Seva, U. Dimensionality Assessment of Ordered Polytomous Items with Parallel Anal. Psych. Meth. 2011, 16, 209-220. [CrossRef]

90. Byrne, B.M. Structural Equation Modeling with AMOS: Basic Concepts, Applications, and Programming; Routledge: New York, NY, USA, 2013.

91. Hair, J.F.; Black, W.C.; Babin, B.J.; Anderson, R.E. Multivariate Data Analysis, 8th ed.; Prentice Hall: Upper Saddle River, NJ, USA, 2018.

92. Gnanadesikan, R. Methods for Statistical Data Analysis of Multivariate Observations; Wiley: New York, NY, USA, 1977.

93. Hu, L.T.; Bentler, P.M. Cutoff criteria for fit indexes in covariance structure analysis: Conventional criteria versus new alternatives. Struct. Equa. Model. 1999, 6, 1-55. [CrossRef]

94. Bollen, K.A. Wiley Series in Probability and Mathematical Statistics. Applied Probability and Statistics Section. Structural Equations with Latent Variables; John Wiley \& Sons: New York, NY, USA, 1989. [CrossRef]

95. Loiacono, C.; Palermi, S.; Massa, B.; Belviso, I.; Romano, V.; Di Gregorio, A.; Sirico, F.; Sacco, A.M. Tendinopathy: Pathophysiology, Therapeutic Options, and Role of Nutraceutics. A Narrative Literature Review. Medicina 2019, 55, 447. [CrossRef]

96. Jiménez-Vaquerizo, E. Metodologías Activas de Aprendizaje en el aula: Apuesta por un Cambio de Paradigma Educativo; Editorial Aula Magna: Sevilla, Spain, 2019.

97. Ventosa, V.J. Métodos Activos y Técnicas de Participación para Educadores y Formadores; Editorial CCS: Madrid, Spain, 2004.

98. Yuretich, R.F. Encouraging critical thinking: Measuring skills in large introductory science classes. J. Coll. Sci. Teach. 2003, 33, 40-45.

99. Pérez-López, I.; Rivera García, E. Formar docentes, formar personas: Análisis de los aprendizajes logrados por estudiantes universitarios desde una experiencia de gamificación. Signo Y Pensam. 2017, 70, 112-129. [CrossRef]

100. Comité de Expertos de EF del Consejo COLEF. Posicionamiento del colectivo del área de educación física sobre las mejoras para una educación física de calidad en España. REEFD 2017, 417, 73-81.

101. Casey, A. Cooperative Learning through the eyes of a teacher-researcher and his students. In Cooperative Learning in Physical Education: A Research-Based Approach; Dyson, B., Casey, A., Eds.; Routledge: London, UK, 2012; pp. 75-87.

102. Bárcena, J.O.; Zulaika, L.M. Cómo implementar el Aprendizaje Cooperativo en la formación inicial del profesorado? Un ejemplo práctico en la asignatura "Juego y Deporte". In Metodologías Activas en Ciencias del Deporte (V.II); Baena-Extremera, A., Ruiz Montero, P., Eds.; Editrial Wanceulen: Sevilla, Spain, 2019; pp. 97-118. 
103. Kolovelonis, A.; Goudas, M. Students' recording accuracy in the reciprocal and the self-check teaching styles in physical education. Educ. Res. Eval. Int. J. Theory Pr. 2012, 18, 733-747. [CrossRef]

104. Muros, J.J.; Som, A.; Leyva, A.I.; Zabala, M. Efecto de dos estilos de enseñanza (cognoscitivo versus tradicional) sobre el aprendizaje de conceptos de anatomía muscular en alumnos de Educación Física de $1^{\circ}$ de ESO. Apunt. Educ. Física Y Deportes 2010, 100, 23-31.

105. Brockbank, A.; McGill, I. Aprendizaje Reflexivo en la Educación Superior; Morata: Madrid, Spain, 2002.

106. Zapatero-Ayuso, J.A.; González-Rivera, M.D.; Campos-Izquierdo, A. La formación de los docentes de Educación Física en torno a la enseñanza por competencias a través de un grupo de discusión. Emásf 2012, 17, 6-20.

107. Evangelio, C.; González-Víllora, S.; Serra-Olivares, J.; Pastor-Vicedo, J.C. El Modelo de Educación Deportiva en España: Una revisión del estado de la cuestión y prospectiva. Cuad. Psicol. Dep. 2016, 16, 307-324.

108. Metzler, M. Instructional Models in Physical Education; Taylor \& Francis: New York, NY, USA, 2017.

109. Sicilia-Camacho, A.; Brown, D. Revisiting the paradigm shift from the versus to the non-versus notion of Mosston's Spectrum of teaching styles in physical education pedagogy: A critical pedagogical perspective. Phy. Educ. Sport Pedag. 2008, 13, 85-108. [CrossRef]

110. Hortigüela, D.; Pérez-Pueyo, A.; Fernández-Río, J. Implantación de las competencias: Percepciones de directivos y docentes de educación física. Rev. Int. Med. Cienc. Act. Física Deporte 2017, 17, 261-281. [CrossRef]

111. Pérez, A.; Hortigüela, D. ¿Y si toda la innovación no es positiva en Educación Física? Reflexiones y consideraciones prácticas. Retos: Nuevas Tend. En Educ. 2020, 37, 579-587. [CrossRef]

112. Hein, V.; Ries, F.; Pires, F.; Caune, A.; Emeljanovas, A.; Heszterane, E.; Valantiniene, I. The relationship between teaching styles and motivation to teach among physical education teachers. J. Sports Med. 2012, 11, 123-130.

113. Velázquez, C. Aprendizaje cooperativo en Educación Física: Estado de la cuestión y propuesta de intervención. Retos 2015, 28, 234-239. 